ISSN 2414-1143

Научный альманах стран Причерноморья. 2019. Том 20. № 4

DOI 10.23947/2414-1143-2019-20-4-50-54

UDC 331:316.6

\title{
SOCIO-PSYCHOLOGICAL CHARACTERISTICS OF RUSSIAN LABOUR MIGRANTS FROM CENTRAL ASIA
}

\author{
(C) Svetlana D. Gurieva \\ Saint Petersburg State University, Saint Petersburg, Russian Federation \\ gurievasv@gmail.com
}

\begin{abstract}
Migration for economic reasons is the movement of people for the purpose of employment and adequate remuneration. Labour migration can be caused for reasons such as the desire to change jobs, sociocultural, housing, environmental, natural, climatic and other conditions. Only older people or people with disabilities can do without a developed economy and social sphere; all the others are included in the circle of potential migration, while the socio-psychological portrait of migrants is heterogeneous. Economic and social changes in modern society have led to intensive and extensive activities of migrants. The article provides an overview of the social, psychological and gender aspects of migration from three countries of Central Asia (former Soviet republics) Kyrgyzstan, Tajikistan and Uzbekistan to Russia (St. Petersburg). The main goal of our study was to identify the socio-psychological mechanisms of migration from Central Asia, the general and specific features of the process of acculturation of labour migrants. The study participants were labour migrants from Tajikistan, Kyrgyzstan and Uzbekistan. The study was conducted in St. Petersburg. In total, 98 people aged 19 to 42 years participated in the study $(M D=32.26, S D=3.44)$, among them women $-44 \%$, men - 56\%. Three ethnic groups presented our sample: Kyrgyz (34 people), Tajiks (32 people) and Uzbeks (32 people). The study revealed both general and specific features associated with certain ethnic groups. The results of the study show that there are significant differences between migrants from Kyrgyzstan, Tajikistan and Uzbekistan in the following acculturation indicators: the number of social contacts (friends) among representatives of their nationality and the Russian-speaking population, type of acculturation strategy, degree of satisfaction with life, cultural and economic security, level of anxiety.

Key words: migration processes, social mobility, labor migrants, adaptation.
\end{abstract}

\section{[С.Д. Гуриева Социально-психологические характеристики трудовых мигрантов России из стран центральной Азии]}

Миграция по экономическим причинам - это перемещение людей с целью трудоустройства и адекватного вознаграждения. Трудовая миграция может быть вызвана по таким причинам как желание сменить место работы, социально-культурные, жилищные, экологические, природные, климатические и другие условия. Только пожилые люди или инвалиды могут обойтись без развитой экономики и социальной сферы; все остальные входят в круг потенциальной миграции, при этом социальнопсихологический портрет мигрантов неоднороден. Экономические и социальные изменения в современном обществе привели к интенсивной и обширной деятельности мигрантов. Статья содержит обзор социальных, психологических и гендерных аспектов миграции из трех стран Центральной Азии (бывшие советские республики) - Кыргызстана, Таджикистана и Узбекистана - в Россию (СанктПетербург). Основной целью нашего исследования было выявление социально-психологических механизмов миграции из Центральной Азии, общих и специфических особенностей процесса аккультурации трудовых мигрантов. Участниками исследования были трудовые мигранты из Таджикистана, Кыргызстана и Узбекистана. Исследование проводилось в Санкт-Петербурге. Всего в исследовании приняли участие 98 человек в возрасте от 19 до 42 лет (MD = 32,26, SD =3,44), среди них женщины 44\%, мужчины - 56\%. Три этнические группы представили нашу выборку: киргизы (34 человека), таджики (32 человека) и узбеки (32 человека). Исследование выявило как общие, так и специфические особенности, связанные с определенными этническими группами. Результаты исследования показывают, что существуют значительные различия между мигрантами из Кыргызстана, Таджикистана и Узбекистана по следующим показателям аккультурации: количество социальных контактов (друзей) среди представителей своей национальности и русскоязычного населения, тип стратегии аккультурации, степень удовлетворенность жизнью, культурная и экономическая безопасность, уровень тревожности.

Ключевые слова: миграционные процессы, социальная мобильность, трудовые мигранты, адаптация. 
Svetlana D. Gurieva - Ph.D. (Advanced Doctorate) in Psychology, Professor, Saint Petersburg State University, Saint Petersburg, Russian Federation.

Гуриева Светлана Дзахотовна - доктор психологических наук, профрессор, Санкт-Петербургский государственный университет, г. Санкт-Петербург, Российская Федерация.

The emergence of forced and voluntary migrants over almost three decades of socioeconomic and political reforms has led to intensive and extensive migration processes in Russia, which led to the development of a new direction in social psychology - the psychology of migration, some aspects of which are considered in the report. The author conducted a study whose main purpose was to identify the psychological mechanisms that contribute to the adaptation of migrants, considered as one of the most important indicators of the socio-political and psychological stability of society in migrants; places of residence. The study used focus group technique. A content analysis of the responses received at the focus group sessions was conducted. During these sessions, participants were free to share their opinions on questions asked by psychologists. The data obtained allowed us to draw up a general typology of the socio-psychological state of labour migrants in the central regions of Russia for the reasons and motives of migration. Thus, it has been established that migrants strive to avoid poverty and unemployment from economically depressed small settlements, this is a type of labour migration - "for survival". Migrants from the "privileged" central cities strive to significantly increase their income and improve their quality of life. We call this type of labour migration "in search of the best". Finally, from regions where an unfavorable environment is recorded, structural unemployment is observed, and economic employment opportunities are limited, labour migration to the border regions and abroad is observed. We call this type of migration \& quote; seeking hope for prosperity. In addition to the general factors of migration, the report highlights gender factors of labour migration of women: the phenomenon of gender inequality is considered as a migration factor of women seeking to pursue a professional career. Last years' social, economic and political changes have resulted in growth of intensive and extensive migration activity. The occurrence of compelled and voluntary migrants has brought appearance and development of the new direction of social psychology - psychology of migration. The circle of scientific interests connected with the study of migration, problems of migrants and adaptation processes. In the social-psychological literature, the various models of adaptation to the new conditions of social-cultural environment are considered (Jasinskaja-Lahti I., Liebkind K., J.Berry; Soo-Kyung Lee, J.Sobal, E.Frongillo). The various social-psychological features of the migrants, emigrants, such as ethnic identity, characteristics of psychological adaptation, emotional well-being, mental health are studied. In the Russian scientific literature, the following problems are considered: the emigrants' experience of interaction with the representatives of foreign culture (N.S. Khrustaleva), the degree of cultures' similarity (T.G. Stefanenko), personal features of the emigrants (S.H. Schwartz, E. Prince-Gibson), the features of ethnic identity (G.U. Soldatova; S.D. Gurieva) and many others. In Russia, the researches of influence of the socialcultural environment on processes of adaptation have started only last 10-15 years ago. The article contains a review of social, psychological and demographic aspects of acculturation of migrants from three countries of Central Asia (former Soviet republic) - Kyrgyzstan, Tajikistan and Uzbekistan - in Russia (St. Petersburg). The research has found both general and specific features related to certain ethnic groups.

Migration can take two forms: forced or voluntary. The most difficult for regulation is a forced form of migrations, as it has a spontaneous and massive character, and transform 
an existing structure of the society. In general, the process of voluntary (natural) migration is a more regulated process. Because of voluntary migration, structural components of society do not experience any transformations.

\section{Object and methods}

The basic hypothesis of the research is as follows: there are both general and specific peculiarities of the acculturation process of migrant workers. There are significant differences in adaptation of migrants from different countries of Middle Asia.

\section{Object of the research}

We selected labour migrants from Tajikistan, Kyrgyzstan and Uzbekistan as respondents, considering data by the Federal State Statistics Service of Russia, which demonstrate that the majority of migrants' inflow to Russia are labour migrants from these countries of Middle Asia. All the respondents have legal permission to stay in the Russian Federation with the purpose of employment. Most of them stay in the RF without families or children. Almost no one has any private dwelling. Their level of knowledge of the Russian language varies from "know" and "understand" levels to fluent speaking (sometimes without any accent). The respondents are descendants from three countries with their own history, culture and language. The survey was conducted in common conditions for all the respondents: at their workplaces or during leisure time.

\section{Methods}

The research was conducted in St. Petersburg. In total, 98 people aged from 19 to 42 years old took part in the research $(\mathrm{MD}=32.26, \mathrm{SD}=3.44)$, among them: women $-44 \%$, men $-56 \%$. Three ethnic groups represent the selection: Kyrgyz people (34), Tajik people (32), and Uzbek people (32). Distribution of respondents by basic social and demographic factors - sex, level of religious commitment, professional status, economic and marital status - in all the three reviewed ethnic groups was equal (we used chi-square, $p>0.05$ ). The unique difference in distribution of the selection by demographic characteristics is the level of education. For example, in the Tajik group, there were more specialists with secondary professional education than in two other groups $(p=0.001)$; more than a half of the Kyrgyz and Uzbek groups had an academic degree or an uncompleted academic degree. The key method of the empiric research is the comprehensive study of acculturation developed by J. Berry for the international project MIRIPS (Mutual Intercultural Attitudes in Plural Societies: the Mirips Progectiv). The procedure includes 27 questionnaires, including 23 for the migrants. The questionnaires for migrants are supposed to obtain the following information: personal details, level of civil and ethnic identity, evaluation of cultural, economic and physical safety, acculturation settings, conceived discrimination, attitude to representatives of other ethnic groups ("Thermometer"), self-satisfaction and lifesatisfaction, evaluation of depression and uneasiness, evaluation of social and cultural disadaptation, "false scale". The method elicits strategies of acculturation used by migrants in the process of interaction with dominate population that consequently may be considered as a factor of successful adaptation.

\section{Results}

Knowledge of the Russian language. The most significant difference between men and women was found in the Uzbek group. In the Kyrgyz group, the knowledge of the Russian language is, in the opposite, higher for men, but the difference is insignificant. The fact that women know the Russian language better than men may be partially explained by the specificity of their work, which usually involves social interaction with local population (shops, public utilities, social institutions), while men migrants are mostly involved in physical labour and often work in groups of their countrymen (like brigades at construction sites).

Social environment (friends). In answers to the question about the nationality of their close friends, we found a significant difference between men and women in all the groups. 
Women more often claimed having friends among both their ethnic group $(p=0.006)$ and Russians ( $p=0.024)$.

At the same time, Tajik and Uzbek people meet their friends significantly more often than Kyrgyz people. This is equally true for their friends of the same ethnicity $(p=0.015$ and $p=0.004$ respectively) and for their Russian friends ( $p=0.000$ and $p=0.000$ respectively). Thus, women have more social contacts with local people than men. At the same time, the Kyrgyz respondents significantly less often meet their friends, compared to Tajik and Uzbek people.

Safety issues. Three types of safety have been studied in this work: economical, physical and cultural. Kyrgyz people feel more economically safe, especially compared to labour migrants from Uzbekistan $(p=0.032)$. Uzbek men feel the least economically safe.

It is possible that the sense of physical insecurity in Kyrgyz men is due to their having less friends compared to Kyrgyz women and representatives of other ethnic groups. Availability of a wide social circle may serve as a kind of buffer, helping to comprehend ambient environment as less dangerous and unpredictable.

Self-satisfaction

For self-satisfaction of the respondents, we elicited gender and ethnic peculiarities. Generally, women in the selection are more self-satisfied than men $(p=0.004)$. This may be especially true for Uzbek women $(p=0.001)$, who are "generally self-satisfied" and "feel useful". At the same time, Kyrgyz people demonstrated the lowest values of selfsatisfaction compared to Uzbek people. They wanted "to be respected more" and believed that they are "worth respecting just like others" $(p=0.003)$.

\section{Discussion}

The configuration of factors by the indicators of adaptation of migrant workers from Kyrgyzstan, Tajikistan and Uzbekistan studied in the research includes both common features and specific differences. Thus, in general, the selection demonstrated a sufficiently high level of knowledge of the Russian language, which is a predictor for intercultural adaptation. Educational level of the respondents is no less than secondary or professional (52\%), one third of them have an uncompleted academic degree and about $20 \%$ have a completed academic degree, which may also enhance successful adaptation to another culture. On the average, women demonstrated better knowledge of the Russian language; they had a wider circle of contacts among both their compatriots and local population. They also appeared more sincere than men, who more often gave socially approved answers.

The research results show that there are significant differences between migrants from Kyrgyzstan, Tajikistan and Uzbekistan by the following indicators of acculturation: number of social contacts (friends) among representatives of their own ethnicity and the Russian-speaking population, type of acculturation strategy, degree of life-satisfaction, cultural, physical and economic safety, anxiety level.

\section{Conclusion}

In conclusion, it should be stated that people must not be deprived of their right to search for better conditions of life. However, social psychologists, among others, are responsible for making this process reasonable, manageable and controllable. The closest task is to find answer for the up-to-date questions: is migration without limits possible or should countries put limits to migration?

\section{References}

1. Berry, J. W. Immigration, Acculturation and Adaptation. Applied Psychology: An International Review. 1997. pp. 5-68. 
2. Berry, J. W., Poortinga, Y. H., Segall, M. H., \& Dasen, P. R. Cross-cultural psychology: Research and applications (2nd ed.). Oxford University Press, Inc., 2002. 588 p.

3. Der-Karabetian, A. Relation of two cultural identities of Armenian-Americans. Psychological Reports. 1980. pp. 123-128.

4. Gordon, M. M. Assimilation in American life: The Role of Race, Religion and National Origins. New York: Oxford University Press. 1964.

5. Graves T. Psychological acculturation in a tri-ethnic community. South-Western Journal of Anthropology.1967. pp. 337-350.

6. Gurieva, L.K. Conceptual Foundations of Social Responsibility of Corporate Structures: Historical Aspect, No. 4 (16), 2018. pp. 56-61.

7. Gurieva, L.K. New Strategic Approach to the Innovative Development of Regions. 2016. No. 2 (6), pp. 1-4.

8. Gurieva, L.K., Dzhioev A.V. (2016). Sustainable Development of the Russian Economy. No. 2 (6), pp. 5-8.

9. Gurieva, S., Kinunen, T. Social-psychological Model of the «Migration Circle»: potential emigrants, migrants, remigrants. Open Journal of Social Sciences (JSS), 2014. 2 (11), pp. 174182. doi: 10.4236/jss.2014.211023.

10. Gurieva, S., Kostromina S. N., Tcvetkova L. A., Samuylova I. A., Konfisakhor A. G., Anisimova $T$. V. (2015). Migration as an indicator of people's social and psychological stability (as exemplified in the Pskov Region). Psychology in Russia: State of the Art. 2015.8 (1). 61-73. doi: 10.11621/pir.2015.0106.

11. Hutnik, N. \& Barrett, M. Ethnic minority identity: Twenty years on. Psychology Conference presentations from the Department of Psychology. University of Surrey. 2003. http://epubs.surrey.ac.uk/1625/1/fulltext.pdf

12. Hutnik, $N$. Ethnic minority identity. A social psychological perspective. Oxford: Clarendon Press.1991.

13. Jasinskaja-Lahti, I. \& Liebkind, K. Content and Predictors of the Ethnic Identity of Russianspeaking Immigrant Adolescents in Finland, in: Scandinavian Journal of Psychology. 1998. pp. 209-219. DOI: 10.1177/0022022106286925

14. Jasinskaja-Lahti, I. \& Liebkind, K. Acculturation and psychological well-being among immigrant adolescents in Finland: a comparative study of adolescents from different cultural background. Journal of Adolescent Research. 2000. 15 (4), pp. 446-469.

15. Moghaddam, F. M. Individualistic and collective integration strategies among immigrants: Toward a mobility model of cultural integration. In J. W. Berry \& R. C. Annis (Eds.), Ethnic psychology: Research and practice with immigrants, refugees, native peoples, ethnic groups and sojourners (pp. 69-79). Amsterdam: Swets \& Zeitlinger. 1988.

16. Ravenstein, E. G. The Laws of Migration. Journal of the Royal Statistical Society, 1985. pp. 167-227.

17. Redfield, R., Linton, R. \& Herskovits, M. J. Memorandum on the study of acculturation. American Anthropologist. 1936. pp. 149-152.

18. Sam, D. L. Acculturation of young immigrants in Norway. A psychological and socio-cultural adaptation. Bergen: University of Bergen. 1994.

19. Schwartz, S. H. Universals in the content and structure of values: Theoretical advances and empirical tests in 20 countries. In M. Zanna (Ed.), Advances in experimental social psychology (pp. 1-65). Orlando: Academic Press. 1992.

This research work was supported and funded by the Russian Humanitarian Science Foundation (RHSF) (project № 19-013-00686 A). 